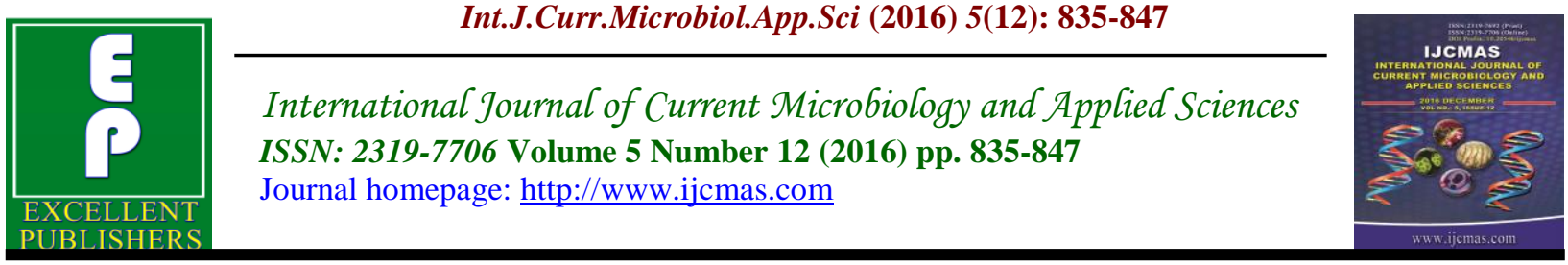

Original Research Article

http://dx.doi.org/10.20546/ijcmas.2016.512.092

\title{
Microbial Profiles of Diabetic Foot Ulcers: A Random Comparison within India
}

\author{
C. Meenakshisundaram ${ }^{1 *}$, J. Uma Rani ${ }^{1}$, Usha Anand Rao ${ }^{2}$, V. Mohan ${ }^{3}$ and R. Vasudevan ${ }^{4}$ \\ ${ }^{1}$ Department of Microbiology, Sri Venkateswara Medical College and Research Centre, \\ Pondicherry-605 102, India \\ ${ }^{2}$ Department of Microbiology, Dr. A.L.M. Post Graduate Institute of Basic Medical Sciences, \\ Tharamani Campus, University of Madras,Chennai-600 013, India \\ ${ }^{3}$ Director, ${ }^{4}$ Surgeon, Dr. Mohan's Diabetic Specialties Research Centre, Gopalapuram, \\ Chenai-600 028, India \\ *Corresponding author
}

\section{Keywords}

Diabetic Foot Ulcer, Anaerobes, Aerobes, Fungal Organisms, Microbiological studies, Rural India.

\section{Article Info}

Accepted:

28 November 2016

Available Online:

10 December 2016

\section{A B S T R A C T}

The present study is an analysis of a retrospective data gathered in Chennai in 2005, in order to compare the bacteriological profiles revealed in Chennai, with the bacteriological profiles reported by other investigators from various other locations in India, as reported in the literature, with a view to incorporate the lessons learnt, for the benefit of future-studies on topics of diabetic foot ulcers. The retrospective study was related to 75 patients receiving treatment for diabetic foot ulcers, in a tertiary health care centre in Chennai City, India, during a period of 5-months from May to September 2005. The patients were screened for bacterial pathogens in their wounds. A total of 104 isolates were obtained. In the microbiological analysis carried out as per standard procedures, the pathogens were identified as i) Escherichia coli (22.2\%), ii) Staphylococcus aureus(17.3\%), iii) Pseudomonas aeruginosa (17.3\%), iv) Klebsiella species (10.6\%), v) Coagulase Negative Staphylococcus (CONS) species (10.6\%), vi)Proteus species (9.6\%), vii) Streptococcus species ( $5.8 \%$ ), viii) Corynebacterium species $(3.8 \%)$,and ix) Enterococcus species (2.9\%). This result was compared with similar findings of 17other Investigators in India (8-from South India and 9-from North India), as obtained in the literature review. This random comparison has been useful to realize the reality that the pathogens found in diabetic foot ulcers could include bacteria (aerobes, anaerobes and facultative-anaerobes) and fungal organisms. This implies that there is a need to carry out the antimicrobial sensitivity tests for all categories of pathogens present in the wound. Considering the potential risk of a trivial injury in diabetic patients getting slowly and surely converted into more serious complications, it may be concluded that all classes of pathogens need to be examined, thoroughly, in the Clinical Microbiology Laboratory attached to each District Headquarters Hospital of the Government, in order to augment the efforts of Clinicians in selecting the appropriate therapies needed for the diabetic foot ulcer patients who, mostly, happen to be hailing from the rural India. No pathogen needs to be ignored or spared! 


\section{Introduction}

In India's around 50.8 millions of the population were affected with diabetes in the year 2010 and the disease is progressing at an alarm ingrate, and the number is likely to increase up to 87.0 million by the year 2030, as estimated by Ramachandran et al., (2010). This statistical report would describe the need for the caution to be shown by all stake-holders, including the susceptible diabetics, the care-takers, and the Government whose major role is to protect public health, in a Welfare State!

Shaw et al., (2010) estimated that an increase of $69.0 \%$ could be expected in the increase of numbers of adults with diabetes in developing countries, and an increase of $20.0 \%$ in developed countries.

American Podiatric Medical Association (APMA) (2016), broadly indicated the possibility that a diabetic foot ulcer as an open sore or wound could occur in about $15.0 \%$ of patients with diabetes, mostly located at the bottom of the foot, and that, among those who develop a foot ulcer, approximately $6.0 \%$ (of them) would have to be hospitalized due to infection. However, they concluded, with an optimistic note, that the development of a diabetic foot ulcer is "preventable".

Viswanathan et al., (2006) reported that the prevalence of foot infection was higher among the rural patients, compared to the urban patients, in addition to highlighting uponthe percentages of amputations or recurrences being higher with rural patients. Mohan et al., (2008), also reported similar views, in addition to reiterating the fact that awareness among the diabetic patients prevailed only among the people in urban and peripheral-urban areas. Therefore, based on studies undertaken by many such investigators in India, the kind of medical care needed in rural areas, in the case of diabetic foot infections, must be up-dated in India, in extending improved facilities of microbiological analysis and antibioticsensitivity-based treatment options, at every District Hospital in India (Meenakshisundaram et al., (2016). It was generally concluded that the diabetic foot ulcer proved itself, at the global level, as the fourth largest killer-disease, and hence the priority.

Louie et al., (1976), using the then-available laboratory techniques, established the fact that aerobic bacteria and anaerobic bacteria could co-exist in the diabetic foot ulcer, and reported that there was a necessity to select antibiotics in such a way as to cover the likelihood of a complex containing aerobic and anaerobic pathogens. Murali et al., (2014) reported that Pseudomonas aeruginosa, as a single pathogen, could exist alone, or co-exist with many other pathogens, such as Acinetobacterspp, Ciprobacterspp, Enterobacterspp, Gramnegative Bacilli, Klebsiella pneumonia, Proteus mirabilis, Proteus vulgaris, Enterococci spp, Methicillin-resistant coagulase-negative staphylococci (CONS) species, Methicillin-resistant Staphylococcus aureus (MRSA), and Methicillin-sensitive Staphylococcus aureus(MSSA), in percentages of combinations varying from $12.0 \%$ to $36.0 \%$. In other words, each pathogen had the flexibility of either prevailing alone, or existing in combination. However, each species seem to have choice of their own preference!

Thus, it is seen that the bacterial diversity in chronic wounds has been established as a reality. The inference is that the pathogens might have a synergistic effect among them, which needs to be investigated in future studies, so that the information gathered in 
these lines would help evolving appropriate treatment methods and management procedures, for achieving a positive and early cure from the illness.

Dixit et al., (2011) conducted a crosssectional study involving the screening of323 diabetic patients across India, and concluded that $87.0 \%$ of diabetic patients in India suffered from foot ulcer or blisters during the first year of on-set. Dixit et al., (2014) reported that the awareness of the diabetic patients was lacking about the footcare which must be given prominence, by healthcare personnel and policy-makers.

Abilash et al., (2015) reported that 18 patients out of 100 suffered from diabetic foot ulcer caused by fungal organisms, the predominant species being i) C. albicans, and ii) C.tropicalis.

Saravanan Sanniyasi, et al., (2015) reported that ulcers of duration more than about 7 or 8 months showed significant positivity in fungal pathogens, and that fungal infections were harboured in 19 patients out of 105 patients studied by them, in Chennai, as against 9 out of 103 patients reported by Bansal et al., (2008).

Uckay et al., (2008) summarised the highlights of 13-Investigators of India, who reported the presence of Gram-negative pathogens to be the most predominant organisms isolated from diabetic foot ulcers in 8-South Indian locations and 5-North Indian locations; whereas, the Gram-positive organisms were reported to be the most predominant pathogens found in diabetic foot ulcers in certain foreign countries, such as Spain, Portugal, Saudi Arabia and Iran, as reported by various investigators, in their respective countries.

Pathare et al., (1998) studied the diabetic foot infections of 252-patients, in Mumbai, isolating 775 clinical strains, which corresponded to $71.09 \%$ of aerobic pathogens, $28.91 \%$ of anaerobic pathogens. This could imply that the anaerobes cannot be overlooked in the evaluation and treatment requirements. Chincholikar et al., (2002) reported that $28.0 \%$ of bacterial isolates collected from diabetic foot ulcers corresponded to anaerobes. Ramani et al., (1991) reported that about $27.3 \%$ of the strains gathered from diabetic foot ulcers of 75-patients were identified as anaerobes. Sapico et al., $(1980 ; 1984)$ reported that the concomitant presence of aerobes and anaerobes could be a reality in diabetic foot infections.

The diversity of micro organism in wounds is influenced by factors such as wound type, depth, location, the level of tissue perfusion, and the immune-competence of the host. In diabetic patients, pre-existing conditions provides nourishment for unhindered bacterial growth.

Gjodsbol et al., (2006) reported that chronic venous leg ulcers accommodate Staphylococcus aureus (in $93.5 \%$ of ulcers), Enterococcus faecalis (in $71.7 \%$ of ulcers), Pseudomonas aeruginosa (in 52.2\% of ulcers), Coagulase negative Staphylococcus (in $45.7 \%$ of ulcers), Proteus species (in $41.3 \%$ of ulcers), and anaerobic bacteria (in $39.1 \%$ of ulcers).

Bowler and Davies (1999) reported that open-wound pathogens are aerobic microbial organisms such as Staphylococcus species and Streptococcus species, and that anaerobic microorganisms, such as Peptostreptococcus species, Prevotella species, Porphyromonas species, Bacteroides species, etc., play a potential role in clinical manifestation of chronic wound infections. These anaerobes may even act synergistically to invade tissues, 
without penetrating deep into the woundcompartment. For this reason, the anaerobes cannot be ignored, in the treatment procedures, and hence, in the microbiological testing routines.

Lipsky et al., (1997) described that aerobic Gram-positive cocci are the major pathogens in diabetic foot infections, and that aerobic Gram-negative bacilli or anaerobes were present in chronic wounds.

The rate of anaerobic infections in diabetic foot ulcers could vary from $5.0 \%$ to $95.0 \%$, as reported by Amalia et al., (2002). Based on such informations, Pednekar et al., (2015) reported that the emergence of resistance against the commonly-used antimicrobial agents (AMAs) was a reality, and therefore, it must be made "mandatory" to record the antimicrobial resistance patterns of anaerobic microbial organisms, concurrently, while recording the antimicrobial resistance patterns of the aerobes, so that the procedures related to the treatment and management of diabetic foot ulcers could get simplified/streamlined.

If the diabetic foot infection, in patients, are not cured by administering antibiotic therapy against the isolated bacterial species, basedon bacterial sensitivity tests, then the possibility of the presence of anaerobic bacteria or fungal organisms can be suspected. Redkar et al., (2000) identified bacterial organisms from non-healing diabetic foot wound by using $16 \mathrm{~S}$ rDNAsequencing and isolated the "missing" organisms.

Shahi et al., (2013) reported the occurrence of multiple antibiotic resistance phenotype and Class1-integron in bacteria isolated from diabetic foot ulcers, involving Gene Cassettes, and Beta-lactamase genes, for many Multi Drug Resistant Organisms encountered in diabetic foot infections in India, by labeling the bacterial species with accession numbers based on 16S rRNA sequence, and identifying the various susceptible antibiotic agents for each pathogen. Such data, if generated in each geographical zone in India, and made available for the guidance of clinicians practicing in various parts of India, it would be of immense benefit to those who suffer from diabetic foot infections.

The present study was conducted with the following aim and objective: To compare the data relating to the various pathogens in diabetic foot ulcers, as identified in the retrospective study, undertaken in Chennai, during 2005 , with similar results reported by other investigators in different locations of India. And also to improve upon the understanding of the shortcomings, if any, in the retrospective study, so that suitable modifications in future studies, can be incorporated, with regard to revised approaches in methodologies, as contributions from other investigators.

\section{Materials and Methods}

Pus swabs were collected from 75 patients attending Dr. V. Mohan's Diabetes Specialties Center, Gopalapuram, Chennai600028 (South India),during a period of 5months, from May to September 2005. These pus samples were transported to the Laboratory in Carry-Blair transport medium (Hi-Media, Mumbai, India). All the isolates were identified, adopting the standard procedures spelled out in NCCLS of 2002 (Meenakshisundaram et al., 2015).

\section{Results and Discussion}

The percentages of prevalence of different bacterial species isolated from the 104samples are presented in Table-1, and 
depicted in Figure-1. Among a total of 75 patients, selected in the study group, the wound categories were found to correspond to Wagner's Grades2,3,4 and 5, pertaining to diabetic foot ulcer.

This data of the retrospective study were compared with the findings of other investigators in India (8-scholars from South India, and 9-scholars from North India). The 16-locations covered in this comparison are: Chennai, Chidambaram, Karaikal, Salem, Bengaluru, Thiruvananthapuram, Kochi (Cochin), Calicut (Kozhikodu), Manipal (9cities representing South India), and, Mumbai, Ahmedabad, Chandigarh, New Delhi, Lucknow, Allahabad, Aligarh and Kolkata ( 8-cities representing North India). The details are shown in Table- 2 .

The prevalence of the various (nine) species of bacteria isolated in the retrospective study of 2005, in Chennai (as listed in Table-1), generally, agree with the results reported by many other Investigators in India (listed in Table-2), in so far as the presence of specific pathogen in the wounds of patients at each site is concerned, although the percentages of prevalence of each bacterial species varied from place to place, obviously due to the differences in the "statuses" of the wounds encountered, in terms of Wagner Grades, in each place.

The percentage of Staphylococcus aureus, Pseudomonas aeruginosa and Escherichia coli, reported as $17.3 \%, 17.3 \%$, and $22.2 \%$, respectively, in Chennai were found to be prevalent, in varying percentages, in all the other 8-South Indian cities, and in all the 8North Indian cities, reviewed.

The percentage of Enterococcus species reported to be present in Chennai at $2.9 \%$, was found to be present, in varying percentages, in the 7-other South Indian cities, and in 6-North Indian cities, reviewed.

The Coagulase Negative Staphylococcus (CONS) species, reported to be present in Chennai at $10.6 \%$, was found to be present, in varying percentages, in the 3-other South Indian cities and in 4-North Indian cities reviewed.

The Klebsiella species reported to be present in Chennai at $10.6 \%$, was found to be present in varying percentages, in 7-other South Indian cities, and in the 6-North Indian cities, reviewed.

The Proteus species reported to be presentin Chennai at $9.6 \%$, was found to be present, in varying percentages, in 6-other South Indian cities, and in all the 8-North Indian cities, reviewed.

The Streptococcus species reported to be present in Chennai at 5.8\%, was found to be present, in varying percentages, in the 7other South Indian cities, and in 4-North Indian cities.

In the case of Corynebacterium species which was recorded as $3.8 \%$ in the retrospective study in Chennai, were found in only 1-other place in South India, namely, Calicut (Kozhikodu), in South India; and were present in varying percentages in 2North Indian cities, namely, Mumbai and Aligarh.

Anaerobes which were not reported in the retrospective study in Chennai, were found prevalent in 1-South Indian city (Chidambaram), and in 3- North Indian cities (Mumbai, New Delhi and Lucknow).

Fungal organisms, which were not reported in the retrospective study in Chennai, were found prevalent in 1-South Indiancity 
(namely, Kochi), and in 3-North Indian cities (namely, Mumbai, Chandigarh, and Kolkata).

The random comparison of microbiological data relating to diabetic foot ulcer, as listed in Table-2, describes the nationwide situation, prevailing over a period of 17years,(by mere coincidence), from the year 1998 to 2015. This exercise of comparison of data has been found useful in ascertaining the importance of evaluating the wholesome microbiological diversity, comprising of aerobes, anaerobes and fungal organisms, so as to help ascertaining the importance of evaluating the antimicrobial sensitivity tests for all these various classes of pathogens, for arriving at a set of comprehensive/optimum treatment strategies/options.

Table.1 Percentage prevalence of bacterial species in diabetic foot ulcers

(Number of isolates $=\mathrm{n}=104$ )

\begin{tabular}{|c|l|l|}
\hline S.no & \multicolumn{1}{|c|}{ Organism } & \multicolumn{1}{|c|}{ No. of isolates(\%) } \\
\hline 1. & Staphylococcus aureus & $18(17.3 \%)$ \\
\hline 2. & Pseudomonas aeruginosa & $18(17.3 \%)$ \\
\hline 3. & Coagulase Negative Staphylococcus (CONS)spp. & $11(10.6 \%)$ \\
\hline 4. & Escherichia coli & $23(22.2 \%)$ \\
\hline 5. & Klebsiella spp. & $11(10.6)$ \\
\hline 6. & Proteus spp. & $10(9.6 \%)$ \\
\hline 7. & Streptococcus spp. & $6(5.8 \%)$ \\
\hline 8. & Corynebacterium spp. & $4(3.8 \%)$ \\
\hline 9. & Enterococcus spp. & $3(2.9 \%)$ \\
\hline
\end{tabular}

Fig.1 Prevalence of bacterial species in the Diabetic Foot Ulcer-wound

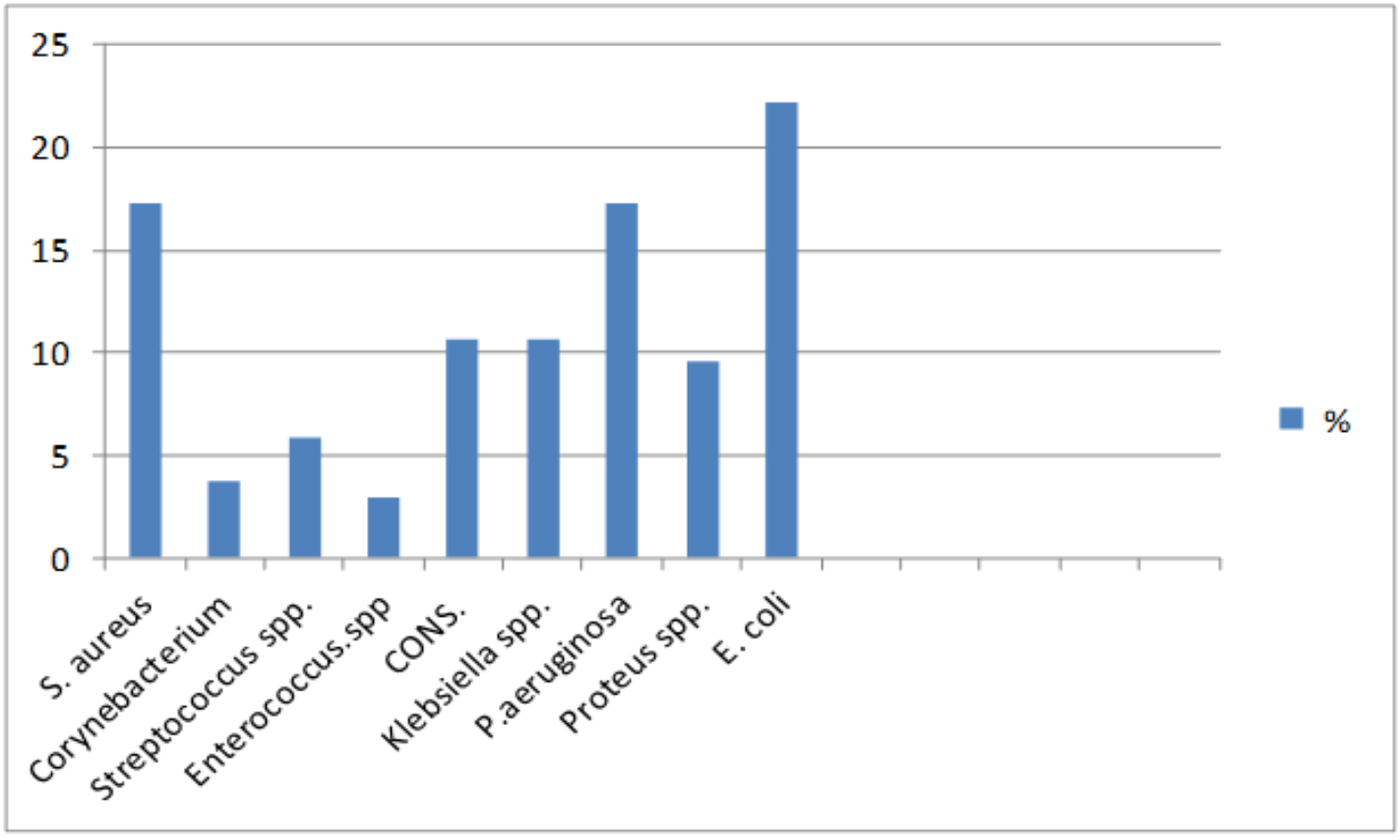


Table.2 Percentage Distribution of Pathogens in Diabetic Foot Ulcers

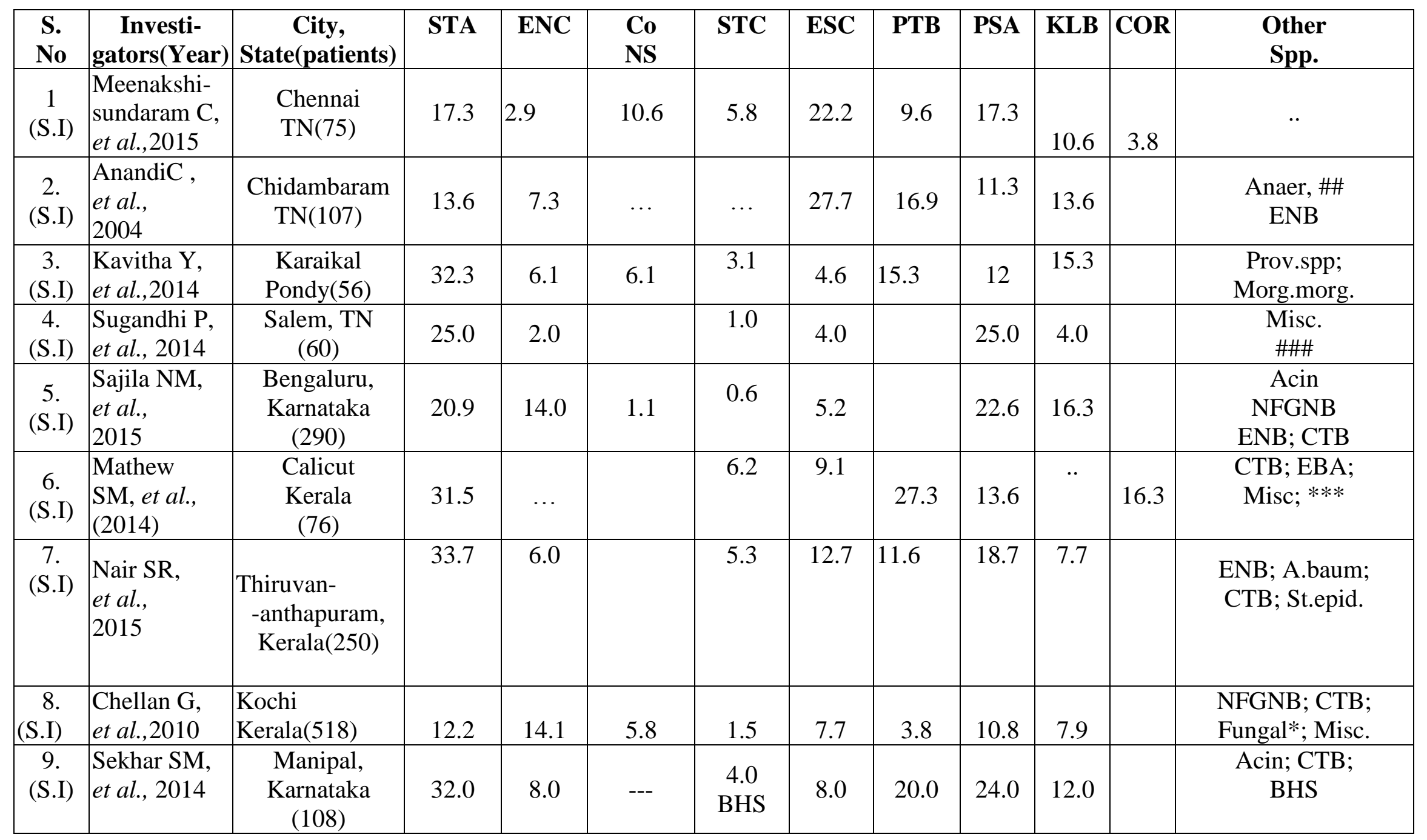




\begin{tabular}{|c|c|c|c|c|c|c|c|c|c|c|c|c|}
\hline $\begin{array}{c}\text { S. } \\
\text { No }\end{array}$ & $\begin{array}{c}\text { Investi- } \\
\text { gators(Year) }\end{array}$ & $\begin{array}{c}\text { City, } \\
\text { State(patients) }\end{array}$ & STA & ENC & $\begin{array}{l}\text { Co } \\
\text { NS }\end{array}$ & STC & $\overline{\text { ESC }}$ & PTB & PSA & KLB & COR & $\begin{array}{l}\text { Other } \\
\text { Spp. }\end{array}$ \\
\hline $\begin{array}{l}10 . \\
(\mathrm{N} . \mathrm{I})\end{array}$ & $\begin{array}{l}\text { Chincholikar } \\
\text { DA,et } \\
\text { al.,2002 }\end{array}$ & $\begin{array}{l}\text { Mumbai } \\
\text { Maha- } \\
\text { rashtra(105) }\end{array}$ & 31.2 &.. &.. & 10.0 & 15.6 & $6.3 ?$ & 19.4 & 8.1 & .. & $\begin{array}{l}\text { Anaer; Fungal; } \\
\text { Serr.marce; } \\
\text { ENB; CTB; +++ }\end{array}$ \\
\hline $\begin{array}{l}11 . \\
(\mathrm{N} . \mathrm{I})\end{array}$ & \begin{tabular}{|l} 
Pathare NA, \\
et al., 1998
\end{tabular} & $\begin{array}{l}\text { Mumbai } \\
(252)\end{array}$ & $\begin{array}{l}19.2 \\
\text { Stp. } \\
\text { Spp }\end{array}$ & 4.3 & .. & 15.6 & 8.9 & 16.7 & $\begin{array}{l}5.4 \\
\text { Pse. } \\
\text { Spp }\end{array}$ & 14.0 & 0.005 & $\begin{array}{l}\text { Anaer; Fungal; } \\
\text { Morg.spp; ETB; } \\
\text { CTB; Acin; } \\
\text { Prov.spp; Serr.spp; } \\
\text { Moraxella spp. }\end{array}$ \\
\hline $\begin{array}{l}12 . \\
(\mathrm{NI})\end{array}$ & $\begin{array}{l}\text { Manisha J, } \\
\text { et al., } 2012\end{array}$ & $\begin{array}{c}\text { Ahme- } \\
\text { dabad } \\
\text { Gujarat(125) }\end{array}$ & 12.7 & & 4.5 & & 16.6 & 4.4 & 30.6 & 20.3 & & $\begin{array}{l}\text { CTB; Morg.Morg; } \\
\text { Prov.rett; Prov.stu. }\end{array}$ \\
\hline $\begin{array}{l}13 . . \\
\text { (N.I) }\end{array}$ & $\begin{array}{l}\text { Bansal E, } \\
\text { et al., } \\
2008\end{array}$ & $\begin{array}{c}\text { Chandigarh } \\
\text { Haryana } \\
((103)\end{array}$ & 19.0 & 5.0 & & & 18.0 & 11.0 & 22.0 & 21.0 & & $\begin{array}{l}\text { Fungal; Acin; } \\
\text { CTB }\end{array}$ \\
\hline $\begin{array}{l}14 . \\
(\mathrm{N} . \mathrm{I})\end{array}$ & $\begin{array}{l}\text { Gadepalli } \\
\text { R,et al., } \\
(200)\end{array}$ & $\begin{array}{l}\text { New Delhi } \\
\quad(80)\end{array}$ & 13.7 & 11.5 & 6.6 & .... & 12.0 & 12.6 & 9.8 & & & $\begin{array}{l}\text { Anaer; Acin; } \\
\text { Micro-coc; } \\
\text { ENB; CTB. }\end{array}$ \\
\hline $\begin{array}{l}15 . \\
\text { (N.I) }\end{array}$ & $\begin{array}{l}\text { Ramkant P, } \\
\text { et al.,2011 }\end{array}$ & $\begin{array}{l}\text { Lucknow } \\
\text { U.P, (447) }\end{array}$ & 13.8 & 9.5 & 5.0 & 3.0 & 16.1 & 8.8 & 15.8 & 6.7 & & $\begin{array}{l}\text { Anaer; Acin; } \\
\text { Sterile strains; } \\
\text { ENB; CTB. }\end{array}$ \\
\hline
\end{tabular}




\begin{tabular}{|c|c|c|c|c|c|c|c|c|c|c|c|c|}
\hline $\begin{array}{l}\text { S. } \\
\text { No }\end{array}$ & $\begin{array}{c}\text { Investi- } \\
\text { gators(Year) }\end{array}$ & $\begin{array}{c}\text { City, } \\
\text { State(patients) }\end{array}$ & STA & ENC & $\begin{array}{l}\text { Co } \\
\text { NS }\end{array}$ & STC & ESC & PTB & PSA & KLB & COR & $\begin{array}{l}\text { Other } \\
\text { Spp. }\end{array}$ \\
\hline $\begin{array}{l}16 . \\
\text { (N.I) }\end{array}$ & $\begin{array}{l}\text { VermaSK, et } \\
\text { al., } \\
2015\end{array}$ & $\begin{array}{l}\text { Allahabad } \\
\text { U.P.(60) }\end{array}$ & 31.5 & .. & .. & 14.0 & 7.0 & 21.0 & 15.8 & .. & .. & $\begin{array}{l}\text { Pepto; Cl.bot; } \\
\text { S.typhi. }\end{array}$ \\
\hline $\begin{array}{l}17 . \\
(\mathrm{NI})\end{array}$ & $\begin{array}{l}\text { Zubair M, } \\
\text { et al.,2011 }\end{array}$ & $\begin{array}{l}\text { Aligarh } \\
\text { U.P.(60) }\end{array}$ & 28.0 & 4.0 & 2.6 & $\begin{array}{c}6.6 \\
\text { BHS }\end{array}$ & 26.6 & 2.6 & 10.6 & 11.9 & 2.6 & $\begin{array}{l}\text { Acin; } \\
\text { ENB. }\end{array}$ \\
\hline $\begin{array}{c}18 . \\
\text { (N.I) }\end{array}$ & $\begin{array}{l}\text { Chakraborty } \\
\mathrm{P}, \text { et al., } 2015\end{array}$ & $\begin{array}{c}\text { Kolkata } \\
\text { Bangla(90) }\end{array}$ & 23.8 & 6.9 & .. & .. & 33.6 & 4.9 & 9.9 & 14.8 & & Fungal \\
\hline
\end{tabular}

Anaer: Anaerobes; Acin: Acinetobacter spp; A.baum: Acinetbacter baumannii; Bac: Bacillus spp; BHS: Beta haemolytic Streptococcus : C.div : Citrobacter diversus; CONS :Coagulase Negative Staphylococcus spp; CTB: Citrobacter spp;Cl.bot :Clostridium botulinum; COR: Corynebacterium spp; Diph.spp: Diphtheroid spp; EBA: Enterobacter aerogenes.; ENB: Enterobacter spp; ENC: Enterococcus spp; ESC: Escherichia coli; (MDR-E.coli: Multi Drug Resistant E.coli); Fungal:Fungal organisms; GNC: Gram-Negative cocci spp; KLB: Klebsiella spp; LB: Lacto bacillus spp; Morg.morg: Morganella morganii; Morg.spp:Morganella spp; MRSA; Methicillin Resistant Staphylococcus aureus; MSSA: Methicillin Resistant Staphylococcus aureus; NFGNB: Non Fermenting Gram-Negative Bacilli; Pepto: Peptococcus spp; Pse.spp: Pseudomonas spp. PTB: Proteus spp; PSA: Pseudomonas aeruginosa; Prov.rett: Providencia rettgeri; Prov.stu: Providencia stuarti; Prov.spp: Providencia spp; Serr.spp: Serratiaspp; Serr.merce: Serratia mercenscens; S.typhi: Salmonella typhimurium; STA: Staphylococcus aureus; STP spp: Staphylococcus spp; St.epid: Streptococcus epidermidis; STC: Streptococcus spp; (OST: Other Streptococcus spp); TN : Tamil Nadu (State); U.P : Uttar Pradesh (State); Pondy : Pondicherry (Puduchery : State).\# Bansal E,et.al,2008: reported Candida spp.\#\# Anandi C, et.al, 2004, reported Anaerobes in Wagner Grades 2, 3, 4 and 5-only.\#\#\# Sugandhi, et al.,2014, reported Staphylococcus saprophyticus, and Staphylococcus epidermidis. Micrococcus spp; Pleisomonas spp; Bacillus spp; Salmonella spp; and Vibrio spp.*** Mathew, et al.,2014, reported Salmonella typhi; Lactobacillus spp; Staphylococcus epidermidis; Bacillus spp; ++ Chellan G, et.al,2010, reported MDR-E.coli; Diphtheroides spp; Serratiaspp; Morganella morganii; Citrobacter diversus;++ Chincholikar, etal., 2002, reported Enterobacter aerogenes; Serratia marcescens; 
Facilities for the application of advanced techniques such as rDNA PCR, ERIC PCR, $16 \mathrm{~S}$ rDNA sequencing, etc, have become feasible, in the modern times of today, to evaluate the infection-status and the bacterial diversity of the isolates in diabetic foot ulcer-wounds (Singh et al., 2009; Redkar et al., 2000; Dowd et al., 2008). These facilities must be made available in all Government Hospitals located in major commercial cities of India, in order to catch up with the facilities available in advanced countries, considering the widely publishedcaution that the Indian population affected with diabetic foot infections would reach alarming proportions by the year 2030 .

In conclusion, a comprehensive analysis of the findings of the various investigators in India will be helpful to arrive at a consensus that the microbiological analysis of clinical isolates must cover the aerobic bacteria, anaerobic bacteria and fungal species, and also include evaluation of the antibiotic sensitivity patterns of these organisms, in order that an early and timely cure can be obtained. The collection of microbiological data becomes necessary at every stage of treatment, in order to form the basis for selecting any specific therapeutic option, and therefore the Clinical Microbiology Laboratory must be upgraded with modern facilities, with respect to equipments and staffing pattern.

\section{Acknowledgement}

The authors are grateful to the various other investigators whose scientific contributions and data have been quoted in this article.

\section{References}

Abilash, S., Kannan, N.S., Rajan, K.V., Pramodhini, M., Ramanathan, M., 2015. "Clinical study on the prevalence of fungal infections in Diabetic foot ulcers", Int. J. Current Res. Review, 7(23): 08-13.

Amalia, C.S., Myrana, M.A., Concepcion, F., 2002. "Microbiologic and Clinical profile of anaerobic diabetic foot infections", Phil. J. Microbiol. Infect. Dis., 31(2): 54-63.

American Podiatric Medical Association (APMA). 2016. "Diabetic Wound Care",www.apma.org/Learn/FootHealt h.cfm?Item Number $=981$.

Anandi, C., Alaguraja, D., Natarajan, V., Ramanathan, M., Subramaniam, C.S., Thulasiram, M., and Sumithra, S. 2004. "Bacteriology of Diabetic Foot Lesions", Indian J. Med. Microbiol., 22(3): 175-178.

Bansal, E., Garg, A., Bhatia, A., Attri, A.K., Chander, J., 2008. "Spectrum of Microbial Flora in Diabetic Foot Ulcers", Indian J. Pathol. Microbiol., 51: 204-208.

Bowler, P., Davies, P. 1999. "The microbiology of acute and chronic wounds", Wounds, 11(4): 72-78.

Chakraborty, P., Mukherjee, S. 2015. "Spectrum and Microbiology of Diabetic Foot Ulcer", Int. J. Sci. Engi. Technol., 3(5): 1144-1146.

Chellan, G., Sivaprakash, S., Ramaiyar, S.K., Varma, A.K., Varma, N., Sukumaran, M.T., Vasukutty, J.R., Bal, A., Kumar, H. 2010. "Spectrum and Prevalence of Fungi infecting Deep tissues of Lower Limb Wounds in Patients with Type-2 Diabetes", $J$. Clin. Microbiol., 48(6): 2097-2102.

Chincholikar, D.A., Pal, R.B. 2002. "Study of Fungal and Bacterial Infections of the Diabetic Foot", Indian J. Pathol. Microbiol., 45(1):15-22.

Dixit, S., Kumar, S. 2014. "Awareness of Diabetic Foot complications in Type 2 Diabetes Populations in Rural India: Are we doing enough?", Diabetes \& 
Metabolism, 5: 363. (doi:10.4172/ 2155-6156.1000363-64.

Dixit, S., Maiya, A., Khetrapal, H., Agarwal, B., Vidyasagar, S., et al., 2011. "A questionnaire based survey on awareness of diabetic foot care in Indian population with diabetes: a cross-sectional multicentre study", Indian J. Med. Sci., 65: 411-423.

Dowd, S.E., Wolcott, R.D., Sun, Y., McKeehan, T., Smith, E., and Rhoads, D. 2008(b). "Polymicrobial Nature of Chronic Diabetic Foot Ulcer Biofilm Infections Determined Using Bacterial Tag Encoded FLX amplicon Pyro sequencing (bTEFAP)", PLOS.ONE, 3(10): e3326. (DOI:10.1371/journal.pone.0003326).

Gadapalli, R., Dhawan, B., Sreenivas, V., et al., 2006, "A Clinico-microbiological studyof diabetic Foot Ulcers in an Indian Tertiary Care Hospital", Diabetes Care, 29:1727-1732.

Gjodsbol, K.,Christensen, J.J., Kartsmark, T., Jorgensen, B., Klein, B.M. et al. 2006. "Multiple bacterial species reside in chronic wounds: a longitudinal study", Int. Wound J., 3: 225-231.

Kavitha, Y., and Khaja Mohiddin, S., 2014, "Bacteriological profile of diabetic foot infections in a tertiary care teaching hospital", Indian J. Basic and Appl. Res., 3(4):260-266.

Lipsky, B.A., 1997, "Osteomyelitis of foot in diabetic foot patients", Clin. Infect. Dis., 25(6): 2819-2828.

Lipsky, B.A. 2004. "Medical Treatment of Diabetic Foot Infections", Clin. Infect. Dis., $\quad 39$ (Suppl.2): $\quad$ S104-S114. (doi:10.1086/383271).

Louie, T.J., Baetlett, J.G., Tally, F.P., and Gorbach, S.I., 1976, "Aerobic and anaerobic bacteria indiabetic foot ulcers", Ann. Intern.Med., 85: 461465.
Manisha, J., Patel Mitesh, H., Sood Nidhi, K., Modi Dashara, J., Vegad, M.M., 2012, "Spectrum of Microbial Flora in Diabetic Foot Ulcerand its Antibiotic Sensitivity Pattern in Tertiary Care Hospital in Ahmedabad, Gujarat", Nat. J. Med. Res., 2(3): 354-357.

Mathew, S.M., and Suchithra, T.V., 2014, "A Threatening Approach of Wound Microflora to Diabetic Ulcer Foot Management", Int. J. Curr. Microbiol. Appl. Sci., ISSN: 2319-7706; Volume 3 Number 9; pp.640-646.

Meenakshisundaram, C., Usha Anand Rao, Rajendran, P., Mohan, V., and Vasudevan, $\quad$ R., 2015 , "Characterisation of Pseudomonas aeruginosa and its association with Diabetic Foot ulcer isolated from a tertiary care hospital in Tamilnadu, India", Int. J. Curr. Microb. App. Sci., ISSN:2319-7706:Vol.4:No.7:pp.122126.

Meenakshisundaram, C., Usha Anand Rao, Rajendran, P., Mohan, V., and Vasudevan, R. 2016. "Drug Resistance of Pseudomonas aeruginosa in Diabetic Foot Ulcers: A Comprehensive Analysis of Data in Indian Cities", Int. J. Curr. Microbiol. App. Sci., 5(10): 724-742.

Mohan, V., Mathur, P., Deepa, R., Shukla, D.K., et al., 2008, "Urban rural differences in prevalence of selfreported diabetes in India -the WHOICMR Indian NCD risk factor surveillance", Diabetes Res. Clin. Pract.,80: 159-168.

Murali, T.S., Kavitha, S., Deepika, J.S., Bhat, V., Bharath Prasad, A.S., Upton, Z., Ramachandra, L., Acharya, V., Satyamoorthy, $\quad$ K., $\quad 2014$, "Characteristics of microbial drug resistance and its correlates in Diabetic Foot Infections", J. Med. Microbiol., 63: 1377-1385. 
Nair, S.R., Rajan, R., Lalithabai, S.D.K., 2015, "A clinico-microbiological study of diabetic foot ulcers from South Kerala", J. Acad. Clin. Microbiologists, 17(2): 94-99.

National Committee for Clinical Laboratory Standard: Performance Standard for Antimicrobial Susceptibility Testing : Twelfth information standard: M100-S 12, Vol.22,no.1, Villanova, $\mathrm{Pa}$, National Committee for Clinical Laboratory Standard, 2002.

Pathare, N.A., Bal, A., Talwalkar, G.V., Antani, D.V., 1998 "Diabetic Foot Infections: A study of microorganisms associated with different Wagner Grades", Indian J. Pathol. Microbiol., 41(4): 437-441.

Pednekar, S.N., Pol, S.S., Kamble, S.S., Deshpande, S.K., Bharadwaj, R.S., Apr. 2015. "Drug resistant anaerobic infections: Are they complicating diabetic foot ulcers?", Int. J. Health care and Biomed. Res., (03): 142-148.

Ramachandran, A., Das, A.K., Joshi, S.R., Yajnik, C.S., Shah, S., et al. 2010. "Current status of diabetes in India and need for novel therapeutic agents", JAPI, 58: 7-9.

Ramani, A., Ramani, R., Shivanandan, P.G., Kundaje, G.N., 1991, "Bacteriology of diabetic foot ulcers", Indian J. Pathol. Microbiol., 34: 81-7.

Ramkant, P., Verma, A.K., Misra, R., Prasad, K.N., Chand, G., Mishra, A., Agarwal, G., Agarwal, A., and Mishra, S.K., Jan.2011, "Changing microbiological profile of pathogenic bacteria in diabetic foot infections: time for a rethink on which empirical therapy to choose?" Diabetologia, 54(1): 58-64.

Redkar, R., Kalns, J., Butler, W., et al., 2000 , "Identification of bacteria from a non-healing diabetes foot wound by 16S rDNA-sequencing", Mol. Cell.
Probes, 14; 14: 163-9. Cross Ref. Medline. Web of Science. Google Scholar.

Sajila, N.M., Manjunath, R, Desai, M., 2015, "A study of Bacteriological Profile of Diabetic Foot Ulcers and Antibiotic Severity Patterns", $J$. Evolution of Med. Dent. Sci., 4(39) May 14: 6832-40.

Sapico, F.L., Canawati, H.N., Witte, J.L., Montgomerie, J.L., Wagner, F.W. Jr., and Bessman, A.W., 1980. Quantitative aerobic and anaerobic bacteriology of infected diabetic feet", J. Clin. Microbiol., 12: 413-418.

Sapico, F.L., Witte, J.L., Canawati, H.N., Montgomerie, J.Z., and Bessman, A.W. 1984. "The infected foot of the diabetic patient: quantitative microbiology and analysis of clinical features", Rev. Infect. Dis., 6suppl.1: S171-6.

Saravanan Sanniyasi, Balu, J., Narayanan, C.D. 2015. "Fungal Infection: A hidden enemy in Diabetic Foot Ulcers", The J. Foot and Ankle Surgery (Asia Pacific), July-Dec ; 2(2):74-76.(10.5005/jp-journals10040-1033).

Shahi, S.K., Kumar, A., Gupta, S.K., and Singh, S.K. 2013. "Occurrence of Multiple antibiotic resistance phenotype and class 1-integron in bacteria isolated from diabetic foot ulcers", African J. Microbiol. Res., 7(48): 5424-5432.

(Doi:10.5897/AJMR12.979).http://ww w.academicjournals.org/AJMR.

Shaw, J.E., Sicree, R.A., Zimmet, P.Z., 2010, "Global estimates of the prevalence of diabetes for 2010 and 2030", Diabetes Res. Clin. Pract., 87: 4-14.

Singh, S.K., Gupta, K., Tiwari, S., Shahi, S.K., Kumar, S., Kumar, A., Gupta, S.K. 2009. "Detecting aerobic 
bacterial diversity in patients with diabetic foot wounds using ERIC-PCR : a Preliminary Communication", The Int. J. Low Extrem. Wounds, 8: 203208.

Sugandhi, P., and Prasanth, D.A. 2014. "Bacteriological Profile of Diabetic Foot Infections", Int. J. Innovative Res. Sci. Engi. Technol., ISSN:23198753; 3(7):14688-14692.

Uckay, I., Gariani, K., Pataky, Z., Lipsky, B.A., July, 2013, "Diabetic Foot Infections: state- of - the -art", Diabetes, Obesity and Metabolism, Review Article. (doi:10.1111/dom.12190/1-12).

Verma, S.K., and Verma, P., 2013,
"Prevalence of Bacterial Infection in Patients with Diabetic Foot Lesions", Int. J. Life- Sci. Scientific Res., (IJLSSR), 1(1): 26-32.

Viswanathan, V., Madhavan, S., Rajasekar, S., Chamukuttan, S., Ambady, R. 2006. "Urban -ruralDifferences in the prevalence of foot complications in South Indian diabetic patients", Diabetes Care, 29: 701-703.

Zubair, M., Malik, A., Ahmad, J. 2010. "Clinico-bacteriology and risk factors for the diabetic foot infections with multidrug resistant microorganisms in North India”, Biol. Med., 2(4): 22-34.

\section{How to cite this article:}

Meenakshisundaram, C., J. Uma Rani, Usha Anand Rao, V. Mohan and Vasudevan, R. 2016. Microbial Profiles of Diabetic Foot Ulcers: A Random Comparison within India. Int.J.Curr.Microbiol.App.Sci. 5(12): 835-847. doi: http://dx.doi.org/10.20546/ijcmas.2016.512.092 